\title{
Pre- and post-calving forage systems and reproductive performance of primiparous cows ${ }^{1}$
}

\author{
José Fernando Piva Lobato² ${ }^{2}$ André Luís Menegaz², Antonio Carlos Gonçalves Pereira ${ }^{3}$
}

\footnotetext{
${ }_{1}^{1}$ Financiado por GAP Agropecuária - Uruguaiana, RS.

2 Departamento de Zootecnia/Faculdade de Agronomia, UFRGS.

${ }^{3}$ GAP Agropecuária - Uruguaiana, RS.
}

ABSTRACT - During pre and post calving periods, it was evaluated the influence of the following forage systems on reproductive performance of primiparous cows: natural pasture during pre and post-calving periods; natural pastures during pre-calving period and improved pastures during post-calving period; improved pastures during pre-calving and natural pasture during post-calving; improved pasture during pre- and post-calving periods. The lowest body weights and body condition scores were observed on cows kept on natural pastures pre-calving (384.3 kg and 3.31; $391.4 \mathrm{~kg}$ and 3.60), followed by those on improved pastures during pre-calving and on natural pasture during post-calving period (424.4 kg and 3.60), finally, cows on improved pasture during pre- and post-calving period (421.2 kg and 3.59). Cows on improved pastures pre and post-calving showed higher body weight and body condition score in the beginning of the breeding season (442.1 kg and 3.76), higher pregnancy rate (82.3\%) and they conceived earlier. Natural system during pre-calving and improved on post-calving and that with improved pasture in pre-calving and natural in post-calving did not differ on weight at the beginning of breeding season (417.2 and $409.8 \mathrm{~kg}$ ) and on pregnancy rate (65.8 and 62.8\%), respectively. However, cows on natural pasture in pre-calving and on improved pasture in post-calving conceived earlier. Cows on natural pastures showed lower weight in the beginning of breeding season (391.2 kg), the lowest pregnancy rate $(52.7 \%)$, and they conceived later. Cows maintained on improved pastures pre- and post-calving improved weight and body condition score at calving and beginning of the breeding season making high reproductive performance possible.

Key Words: body condition, Brangus, improved pastures, natural pastures, pregnancy rate, weights

\section{Sistemas forrageiros pré e pós-parto e desempenho reprodutivo de vacas primíparas}

\begin{abstract}
RESUMO - Durante os períodos pré e pós-parto, foi avaliada a influência de sistemas forrageiros no desempenho reprodutivo de vacas primíparas: pastagem natural nos períodos pré e pós-parto; pastagem natural no pré-parto e pastagem melhorada no pós-parto; pastagem melhorada no pré-parto e pastagem natural no pós-parto; pastagem melhorada nos períodos pré e pós-parto. Os menores pesos e condições corporais foram observados nas vacas mantidas em pastagem natural no pré-parto, (384,3 kg e 3,31; 391,4 kg e 3,60), seguidas daquelas em pastagem melhorada no pré-parto e natural no pósparto (424,4 kg e 3,60); e, por ultimo, das vacas em pastagem melhorada no pré e pós- parto (421,2 kg e 3,59). As vacas em pastagem melhorada no pré e pós-parto tiveram maior peso e condição corporal ao início do acasalamento (442,1 kg e 3,76), maior taxa de prenhez (82,3\%) e emprenharam mais cedo. Os sistemas com pastagem natural no pré-parto e melhorada no pós-parto e aquele com pastagem melhorada no pré-parto e natural no pós-parto não diferiram quanto a peso ao início do acasalamento (417,2 e 409,8 kg) e taxa de prenhez (65,8 e 62,8\%), respectivamente. Entretanto, as vacas em pastagem natural no pré-parto e melhorada no pós-parto emprenharam mais cedo. As vacas mantidas em pastagem natural tiveram o menor peso ao início do acasalamento $(391,2 \mathrm{~kg})$, a menor taxa de prenhez $(52,7 \%)$ e emprenharam mais tarde. Pastagens melhoradas no pré e pós-parto melhoraram os pesos e as condições corporais ao parto e ao início da reprodução, possibilitando alto desempenho reprodutivo.
\end{abstract}

Palavras-chave: Brangus, condição corporal, pastagem natural, pastagem melhorada, pesos, taxa de prenhez

\section{Introduction}

When the nutritional requirements for maintenance, growth, lactation, and reproduction are not supplied, primiparous or first-calf cows present low pregnancy rates due to low or no weight gain, low body condition score in the final third of gestation and first third of lactation caused by the lack of supply of their physiological requirements. 
According to Lobato (2003), the "ideal cow" is the heifer that conceives in the beginning of its first breeding season, gets pregnant in the following years using the available natural resources, and always weans a calf with adequate weight, regardless of year. That author also indicates that a primiparous cow must gain at least $100 \mathrm{~kg}$ since the beginning of the first mating and pregnancy and it has to present minimal body condition score of 3 (in a scale from 1 to 5 ) in order to achieve at least 3.5 to 4 body condition score in the beginning of the second breeding season.

Any beef company that aims to improve its production and productivity indexes must supply the nutritional requirements of its cows (Pötter et al., 1998, 2000; Beretta et al., 2001, 2002). In this context, high pregnancy rates are difficult to obtain in primiparous cows, and therefore they should be managed separately from mature cows, and be fed at higher nutritional levels. According to Vieira et al. (2005b), first- and second-calf cows with calves present the lowest pregnancy rates in cow herds.

In the Brazilian breeding-to-fattening beef production systems based on pastures, investments made to supply the nutritional requirements of first-breeding growing heifers can be lost if these primiparous cows do not conceive in the following year, affecting other productivity indexes of these systems (Pötter et al., 1998; Beretta et al., 2001). Other factors, such as low rainfall during the following seasons or years (Vieira et al. 2005a) or excessive stocking rates (Simeone \& Lobato, 1996; Fagundes et al., 2003) influence forage production and quality, directly affecting the reproductive performance of cows, specially in a more complex and intensive production system (Rosado Jr. \& Lobato, 2009).

Considering that reproductive efficiency of primiparous cows is essential to improve productivity indexes in breeding-to-fattening systems (Beretta et al., 2001, 2002), the present study evaluated forage management alternative during pre- and post-calving period of primiparous Brangus cows at three years of age.

\section{Material and Methods}

The experiment was carried out on São Pedro farm, which belongs to GAP-Genética Agropecuária and located in Uruguaiana, Ibirocai district, in the geographic region called Western Border of the state of Rio Grande do Sul, Brazil, from July $1^{\text {st }}, 2005$ to March $3^{\text {rd }}, 2006$.

Pregnancy diagnosis was performed by rectal palpation, and the pregnant heifers (163) were classified according to pregnancy time (more than 120 days of gestation; from 90 to 120 days of gestation; up to 90 days of gestation). Heifers were randomly distributed into four management system from 7/1/2005 to 11/7/2005: 40 heifers were placed on natural pastures pre- and post-calving; N/P: 41 heifers on natural pastures pre-calving and on improved pastures post-calving; $\mathrm{P} / \mathrm{N}$ : 42 heifers on improved pastures pre-calving and on natural pastures post-calving; 40 heifers on improved pastures pre- and post-calving.

Heifers were placed on natural pastures on 7/1/2005 in a 178-ha paddock, corresponding to a stocking rate of $190 \mathrm{~kg} / \mathrm{ha}$ (0.42 AU/ha). One (1) animal unit (AU) corresponded to $450 \mathrm{~kg}$ body weight. Winter-spring species were introduced on improved pastures. The heifers managed on improved pastures (introduction of ryegrass, Lolium multiflorum Lam) occupied an area of 49 ha during the first 30 experimental days at $689 \mathrm{~kg} / \mathrm{ha}$ (1.5 AU/ha) stocking rate. After this period, heifers were transferred to an 80-ha area, which had been seeded three years earlier with ryegrass, white clover (Trifolium repens), and bird's-foot trefoil (Lotus corniculatus cv. São Gabriel). In addition to natural reseeding by the end of 2004, the area was seeded on top with $35 \mathrm{~kg}$ ryegrass/ha in April, 2005; however, natural species predominated during the period the area was used. A stocking rate of $422 \mathrm{~kg} / \mathrm{ha}$ (0.9 AU/ha) was used. After calving and calf identification, cows and calves returned to the initial 49-ha area with ryegrass. The utilization of these two areas aimed at proper pasture management, did not impaire the development of the improved pastures or animal performance. Stocking rate on natural and improved pastures was not very different due to the change in management after calving.

On 11/7/2005, when the breeding season started, all heifers were managed together on natural pastures, at a stocking rate of $320 \mathrm{~kg} / \mathrm{ha}$. Natural mating was used at a bull:cow ratio of $4 \%$. Bulls had been submitted to breeding soundness evaluation. Pregnancy was diagnosed using ultrasound testing on 3/9/2006, 37 days after bulls had been removed.

At each evaluation period, average forage mass was estimated in each experimental paddock using the comparative method of Haydock \& Shaw (1975). Forage samples were weighed, placed in paper bags, identified according to the paddock and collection date, and dried in forced-ventilation oven at $60^{\circ} \mathrm{C}$ for 72 hours. Forage crude protein (CP) and neutral detergent fiber (NDF) were determined (AOAC, 1984).

Cows were weighed every 28 days. Average daily weight variation (ADWV) was calculated for the interval between two weighings. 
During calving season, cows and calves were evaluated up to 48 hours post-calving.

Every time animals were weighed, body condition was scored based on subcutaneous fat deposition according to Lowman et al. (1976) in a scale from 1 (thin) to 5 (fat).

The experiment was analyzed according to a completely randomized design. Data were submitted to analysis of variance, and means were compared by the Tukey test at $5 \%$, using SAS software package, version 6 (SAS, 1997). Continuous variables with normal distribution were analyzed considering unequal number of replicates. Five cows without at least 18 days of change in the post-calving management systems, three cows that did not calve and 12 cows that lost their calves due to different reasons were removed from the statistical analyses. In the system of pre- and post-calving grazing on natural pastures, 36 cow-calf pairs were used; 38 in the system natural pastures pre-calving and improved pastures post-calving; 35 in the system improved pasture pre-calving and natural pastures post-calving; and 34 in the system of improved pastures pre- and post-calving.

The effect of management systems on pregnancy rate were analyzed by the Chi-Square test (Steel \& Torrie, 1989).

Initial body weight (IBW), initial body condition score (IBCS), calving weight (CBW), body condition score at calving (BCSC), final body weight (FBW), final body condition score (FBCS), average daily weight variation (ADWV), days pre-calving (DPre) and days post-calving (DPost) of cows were analyzed according to the following model:

$$
\mathrm{Y}_{\mathrm{ij}}=\mathrm{u}+\mathrm{T}_{\mathrm{i}}+\mathrm{e}_{\mathrm{ij}} ; \quad \mathrm{i}=1,2,3,4
$$

in which: $Y_{\mathrm{ij}}=\mathrm{IBW}, \mathrm{IBCS}, \mathrm{CBW}, \mathrm{BCSC}, \mathrm{FBW}, \mathrm{FBCS}, \mathrm{ADWV}$, DPre or DPost of the $j^{\text {th }}$ cow, submitted to the $i^{\text {th }}$ system; $\mathrm{u}$ = general mean; $\mathrm{T}_{\mathrm{i}}=$ effect of the " $\mathrm{i}$ " system; $\mathrm{e}_{\mathrm{ij}}=$ effect of the random error associated to each $\mathrm{Y}_{\mathrm{ij}}$ observation.

\section{Results and Discussion}

Cows were submitted to the respective forage systems for 73 days pre-calving and 57 days post-calving, in average, with little variation in the average periods among treatments (Table 1). Initial average body weight and body condition score of cows were not significantly different $(\mathrm{P}>0.05)$ among treatments.

Pre-calving daily weight gain of cows grazing on improved pastures pre-calving were 167 and 154 g/day $(\mathrm{P}>0.05)$, which were higher $(\mathrm{P}<0.05)$ than the losses of 535 and $487 \mathrm{~g} /$ day of the cows grazing on natural pastures precalving ( $\mathrm{P}>0.05)$. Although Hight (1966) states that precalving weights may be confounded with cow pregnancy stage, it is believed that the observed differences resulted from the nutritional levels provided by the improved pasture systems for 76 and 73 days pre-calving, respectively. Average dry matter availability and chemical quality estimates of the improved pastures on 7/1/2005 and 8/15/2005 were $1,340 \mathrm{~kg} \mathrm{DM/ha,} 14.13 \%$ crude protein, and $64.68 \%$ neutral detergent fiber, whereas natural pastures presented estimates of $720 \mathrm{~kg} \mathrm{DM} / \mathrm{ha}$ availability, 8.95\% crude protein, and $71.63 \%$ neutral detergent fiber (Table 2). The applied stocking rates determined low availability in kg $\mathrm{DM} / 100 \mathrm{~kg}$ body weight. The estimates of improved pastures were 3.72 and $8.0 \mathrm{~kg} \mathrm{DM} / 100 \mathrm{~kg}$ body weight, whereas natural pastures presented 9.6 and $7.3 \mathrm{~kg}$ DM/100 kg body weight, respectively. The higher weight gains observed on improved pastures pre-calving were due to the higher protein level and lower neutral detergent fiber content of the pastures. Pötter \& Lobato (2004) worked during the same months with pastures with slightly lower availability, but with quality similar (934 kg DM/ha, 62.43\% neutral detergent fiber, and $12.23 \%$ crude protein) to the improved

Table 1 - Body weight and body condition score (scale of 1 to 5) at calving, at the end of the evaluation period, and daily weight variation in the pre- and post-calving periods

\begin{tabular}{|c|c|c|c|c|}
\hline \multirow[b]{2}{*}{ Item } & \multicolumn{4}{|c|}{ Type of pasture in the pre- and post-calving periods } \\
\hline & $\begin{array}{c}\text { Natural pre- and } \\
\text { post-calving }\end{array}$ & $\begin{array}{l}\text { Natural pre-calving, } \\
\text { improved post-calving }\end{array}$ & $\begin{array}{l}\text { Improved pre-calving } \\
\text { and natural post-calving }\end{array}$ & $\begin{array}{l}\text { Improved pre- } \\
\text { and post-calving }\end{array}$ \\
\hline Initial body weight (kg) & 415.8 & 423.0 & 410.3 & 408.3 \\
\hline Initial body condition score & 3.54 & 3.47 & 3.49 & 3.48 \\
\hline Weight at calving (kg) & $384.3 b$ & $391.4 b$ & $424.4 \mathrm{a}$ & $421.2 \mathrm{a}$ \\
\hline Body condition score at calving & $3.31 b$ & $3.26 b$ & $3.60 \mathrm{a}$ & 3.59a \\
\hline Final body weight (kg) & $391.2 \mathrm{c}$ & $417.2 \mathrm{~b}$ & $409.8 b$ & $442.1 \mathrm{a}$ \\
\hline Final body condition score & $3.41 \mathrm{c}$ & $3.53 b$ & $3.50 \mathrm{bc}$ & $3.76 \mathrm{a}$ \\
\hline \multicolumn{5}{|l|}{ Daily weight variation (kg) } \\
\hline Pre-calving & $-0.535 b$ & $-0.487 b$ & $0.167 \mathrm{a}$ & $0.154 \mathrm{a}$ \\
\hline Post-calving & $0.176 b$ & $0.503 a$ & $-0.219 c$ & $0.410 \mathrm{a}$ \\
\hline Days pre-calving & 68 & 74 & 76 & 73 \\
\hline Days post-calving & 62 & 56 & 54 & 57 \\
\hline
\end{tabular}

a,b: Means in the same row followed by different letters are different $(\mathrm{P}<0.05)$ by Tukey test. 
Table 2 - Average estimates of forage availability and average crude protein and neutral detergent fiber content of the pastures

\begin{tabular}{|c|c|c|c|c|c|c|}
\hline \multirow[t]{2}{*}{ Parameter } & \multicolumn{6}{|c|}{ Date } \\
\hline & $7 / 1^{\text {st }} / 2005$ & $8 / 15^{\text {th }} / 2005$ & $9 / 30^{\text {th }} / 2005$ & $11 / 7^{\text {th }} / 2005$ & $11 / 7^{\text {th }} / 2005^{*}$ & $12 / 19^{\text {th }} / 2005^{*}$ \\
\hline \multicolumn{7}{|l|}{ Natural pastures } \\
\hline Dry matter (kg/ha) & 820 & 620 & 910 & 677 & 769 & 842 \\
\hline Crude protein (\%) & 9.07 & 8.82 & 11.31 & 10.19 & 8.16 & 9.26 \\
\hline Neutral detergent fiber (\%) & 71.78 & 71.48 & 71.13 & 70.73 & 77.07 & 72.92 \\
\hline \multicolumn{7}{|l|}{ Improved pastures } \\
\hline Dry matter (kg/ha) & 1,156 & 1,523 & 1,695 & 1,392 & - & - \\
\hline Crude protein (\%) & 13.55 & 14.71 & 14.32 & 13.84 & - & - \\
\hline Neutral detergent fiber (\%) & 62.78 & 64.57 & 64.64 & 65.28 & - & - \\
\hline
\end{tabular}

*Managed together on natural pastures.

pastures in the present study, and observed that cows presented better body condition score at calving than those grazing on natural pastures with higher availability (2,500 and 3,000 $\mathrm{kg} \mathrm{DM} / \mathrm{ha})$, where selective grazing is possible (Hodgson, 1981). Under similar conditions, Lobato et al. (1998b) also determined higher pre-calving weight gain in primiparous cows grazing on improved pastures as compared to those on natural pastures.

The observed weight loss at the end of gestation with a stocking rate of $190 \mathrm{~kg} / \mathrm{ha}$ on natural pastures emphasizes the need of using moderate stocking rates adjusted to soil class (Streck et al., 2002), to the growth rate of natural pastures during winter, and associated to the previous accumulation of forage reserves by closing areas by the end of summer and beginning of fall or to the use of supplementation.

Forage conditions determined similar calving body weights and body condition scores among cows grazing on improved pastures pre-calving and natural pastures postcalving and those exclusively grazing on improved pastures (424.4 and $421.2 \mathrm{~kg} ; 3.60$ and 3.59, respectively), and higher $(\mathrm{P}<0.05)$ as compared to those grazing on natural pastures pre- and post-calving and improved pastures post-calving (384.3 and $391.4 \mathrm{~kg} ; 3.31$ and 3.26, respectively). These weights were $35 \mathrm{~kg}$ lighter, in average, as compared to those obtained by cows grazing on improved pastures pre-calving. Lobato et al. (1998a) evaluated pre- and post-calving feeding effects on the reproductive efficiency of primiparous $1 / 2$ Nelore $\times 1 / 2$ Devon cows and verified a $42-k g$ difference in calving body weight in cows managed on natural pastures (370.1, 358.6 and $376.4 \mathrm{~kg}$ ) as compared to those grazing on improved pastures $(410.0 \mathrm{~kg})$.

Lobato et al. (1998b), aiming at determining the influence of supplementation and winter-spring improved pastures on the reproductive performance of primiparous Devon cows, observed an average daily weight variation precalving of $65 \mathrm{~g}$ with natural pastures, 567 and $801 \mathrm{~g}$ with two different supplementations of cows on natural pastures, and $1,031 \mathrm{~kg}$ with improved pastures $(\mathrm{P}<0.05)$, and postcalving weights of $324.7 ; 340.0 ; 366.5$ and $399.2 \mathrm{~kg}$, respectively. Consistent with these findings, in the present study, only cows managed on improved pastures, with higher nutritional level, presented calving body weights higher than the initial body weight.

Literature findings on body weight at calving are very variable, as it depends on breed, location, year, heifer rearing effects, weight at conception, etc. Cachapuz et al. (1990), working with primiparous Hereford cows, obtained calving body weights from 252.0 to $301.5 \mathrm{~kg}$. Quadros \& Lobato (1996), also evaluating primiparous purebred and crossbred Hereford cows, observed average calving body weights of $320.7 \mathrm{~kg}$. Gottschall \& Lobato (1996), in primiparous Nelore $\times$ Devon cows, showed that low pre-calving nutritional levels resulted in low calving body weights (average $311.3 \mathrm{~kg}$ ) and low pregnancy rates. Pötter \& Lobato (2004) determined calving body weights of 362.5 and $400.9 \mathrm{~kg}$ in primiparous Hereford and Braford cows, respectively. Vieira et al. (2006) determined in primiparous Nelore cows, an average body weight of $436.0 \mathrm{~kg}$ at a date close to calving, during four years of observations.

Morrison et al. (1999), in a study with multiparous cows presenting moderate body condition score (3-3.5), observed that moderate loss of body reserves in the final third of gestation did not influence subsequent reproductive performance, if forage availability was not limiting to consumption post-calving. In the present experiment, cows grazing on natural pastures pre-calving lost an average of 0.31 points of body condition score until calving.

Cows on improved pastures post-calving presented average body weight variation of 503 and $410 \mathrm{~g} / \mathrm{day}(\mathrm{P}>0.05)$, which was different $(\mathrm{P}<0.05)$ from those managed on natural pastures, whose values were 0.176 and $-0.219 \mathrm{~kg} / \mathrm{day}$. Cows on natural pastures pre-calving presented body weight 
variation of almost $100 \mathrm{~g} /$ day, and higher $(\mathrm{P}>0.05)$ than those grazing on improved pastures both pre- and postcalving due to the pre-calving nutritional restrictions. Lobato et al. (1998a) also found higher and compensatory weight gain post-calving in cows grazing on natural pastures pre-calving and on improved pastures post-calving (334 g/day) as compared to cows managed on improved pastures during both periods ( $231 \mathrm{~g} /$ day).

Weight gain was different $(\mathrm{P}<0.05)$ between both natural pasture systems post-calving. Cows maintained on natural pastures both pre- and post-calving gained 176 g/day, whereas those grazing on improved pastures pre-calving and on natural pastures post-calving lost 219 g/day. This result is partially due to the disturbance caused by the change in the forage system, as observed by Beretta \& Lobato (1998). Ferrell (1982) also observed weight losses in heifers moved to a lower nutritional level system. But, Pilau \& Lobato (2009) used supplementation to promote a better adjustment in this period. The observed body weight change was associated to the higher energy requirement for lactation of growing primiparous cows (NRC, 1996; Freetly, 1999) and to forage availability, which was much lower than the required 2,500 kg DM/ha (Simeone \& Lobato, 1996; Pötter \& Lobato, 2004).

At the end of the experimental treatments, on $11 / 7^{\text {th }} / 2005$, the body weight and body condition score of cows grazing on improved pastures both pre- and post-calving (442.1 kg and 3.76 points) were higher than those obtained with the system of natural pastures pre-calving and improved pastures post-calving and in the system with improved pastures pre-calving and natural pastures post-calving ( $\mathrm{P}<0.05 ; 417.2$ and $409.8 \mathrm{~kg}$, respectively), which were similar. Cows managed exclusively on natural pastures had the lowest final average body weight and body condition score (391.2 kg and 3.41); however, their body condition score was not different $(\mathrm{P}>0.05)$ from that of cows submitted to the system of improved pastures pre-calving and natural pastures post-calving (3.50).

Wiltbank et al. (1962) considered that variations in feeding levels between pre- and post-calving periods have a major effect on reproductive parameters. Pre-calving feeding level significantly influences anoestrus duration, and consequently, the number of cows in the heat in the beginning of the breeding season, with the stronger effects on primiparous than in multiparous cows. Post-calving nutritional level affects conception rate, but in situations where it is possible to supply adequate levels pre-calving, post-calving nutritional levels do not affect heat manifestation. Nevertheless, low pre-calving nutritional levels may be compensated by a better nutritional level post-calving. In that study, uterine involution was observed on $35,38,40$, and 42 days for the high-high, high-low, lowhigh, and low-low nutritional levels, respectively.

Evaluating the effect of different nutritional levels on body condition at calving and post-calving on subsequent reproductive performance, Richards et al. (1986) observed little or no influence on calving-first heat interval in cows with body condition score $>3.0$ in any of the tested levels. Cows with body condition score $\leq 2.5$ that maintained or gained body weight when submitted to intermediate and high nutritional levels post-calving, presented better reproductive responses. Cows with body condition score at calving $\geq 3.0$ did not improve their reproductive performance when fed the highest nutritional levels. Herd \& Sprott (1996) recommended a body condition score at calving of $\geq 3.0$ to obtain good reproductive performance during the next breeding season. Body weights and body condition scores at the beginning of the breeding season were determined on $11 / 7 / 2005$, at the end of the feeding treatments (Table 3).

In herds of mature cows weighing $520 \mathrm{~kg}$ and with 4.5-5.0 body condition score, Rovira (1996) recommends that, in order to obtain good reproductive response, primiparous cows must have $85 \%$ of that weight in the beginning of the breeding season, i.e., around $440 \mathrm{~kg}$, as lower body weights result in longer calving-first heat and calving-conception intervals, as well as lower fertility. In the present study, only cows maintained exclusively on improved pastures achieved this body weight and 3.76 body condition score, which were both significantly $(\mathrm{P}<0.05)$ higher than those obtained in the other feeding systems.

The body condition score of 3.41 obtained in cows grazing exclusively on natural pastures was the lowest at the beginning of the breeding season, which is consistent with the parameters established by Lowman (1985), who associated the maintenance of body condition score during winter in at least 3.0 until the beginning of the breeding season to obtain good reproductive performance results and calving intervals of approximately 365 days. Working with primiparous Hereford cows presenting body condition scores of 3.13 and $3.20(\mathrm{P}>0.05)$ obtained with stocking rates of 240 and $320 \mathrm{~kg} / \mathrm{ha}$ on natural pastures, Quadros \& Lobato (1996) observed pregnancy rates of $96.8 \%$ and $86.8 \%$, respectively $(\mathrm{P}>0.05)$.

Cows submitted to all feeding systems lost weight during the first half of the breeding season, particularly those on improved pastures post-calving $(\mathrm{P}<0.05 \%-186$ and -203 g/day), and those grazing improved pastures precalving, as compared to those grazing natural pastures post-calving (-54 and -102 g/day). These losses were due to 
Table 3 - Body weight and body condition score (scale from 1 to 5) at the beginning and end of the breeding season, and average daily weight variation during the breeding season

\begin{tabular}{|c|c|c|c|c|}
\hline \multirow[b]{2}{*}{ Item } & \multicolumn{4}{|c|}{ Type of pasture in the pre- and post-calving periods } \\
\hline & $\begin{array}{l}\text { Natural pre- } \\
\text { and post-calving }\end{array}$ & $\begin{array}{l}\text { Natural pre-calving and } \\
\text { improved post-calving }\end{array}$ & $\begin{array}{l}\text { Improved pre-calving } \\
\text { and natural post-calving }\end{array}$ & $\begin{array}{l}\text { Improved pre- } \\
\text { and post-calving }\end{array}$ \\
\hline Body weight beginning breeding season (kg) & $391.2 c$ & $417.2 b$ & 409.8b & $442.1 \mathrm{a}$ \\
\hline Body condition score beginning breeding season & $3.41 \mathrm{c}$ & $3.53 b$ & $3.50 \mathrm{bc}$ & $3.76 a$ \\
\hline Body weight end of breeding season (kg) & $399.1 c$ & 417.3b & $416.2 b$ & $442.7 \mathrm{a}$ \\
\hline Body condition score end breeding season & $3.40 \mathrm{~b}$ & $3.48 \mathrm{ab}$ & 3.49ab & $3.57 \mathrm{a}$ \\
\hline Daily weight variation first half breeding season $(\mathrm{kg})$ & $-0.054 a$ & $-0.186 b$ & $-0.102 \mathrm{a}$ & $-0.203 b$ \\
\hline Daily weight variation second half breeding season (kg) & 0.237 & 0.185 & 0.248 & 0.211 \\
\hline Daily weight variation during entire breeding season (kg) & 0.093 & 0.001 & 0.075 & 0.007 \\
\hline
\end{tabular}

Means at same line, followed by different letters, differed $(\mathrm{P}<0.05)$ by Tukey test.

the low dry matter availability in all systems ( $806 \mathrm{~kg} / \mathrm{ha}$, with $6.0 \mathrm{~kg} / 100 \mathrm{~kg}$ body weight, $8.71 \%$ crude protein, and $74.99 \%$ neutral detergent fiber). Using similar forage availability (820 kg/DM/ha), Simeone \& Lobato (1996) also determined $337 \mathrm{~g}$ daily weight loss during the first half of the breeding season. Pötter \& Lobato (2004), with forage offer higher than $2500 \mathrm{~kg} / \mathrm{DM} / \mathrm{ha}$, obtained 223 g/day weight gain, whereas cows moved from improved pastures to natural pastures, despite the forage availability of 3,600 kg/DM/ha, gained only $116 \mathrm{~g} /$ day.

The lower weight gain in cows leaving improved pastures, consistent with the findings of Pötter \& Lobato (2004), as well as the weight loss observed in the present study and in the work by Simeone \& Lobato (1996), may be explained by the qualitative or quantitative feed restriction to which the animals were submitted in the subsequent period (Allden, 1981) and by the peak of nutritional requirements that occurs from the final third of gestation until the peak of lactation, 2.5-3 months post-calving (Freetly, 1999). Rocha et al. (2004) determined weight losses of $185 \mathrm{~g}$ /day in heifers moved from improved pastures to natural pastures. Lobato et al. (1998a,b) also observed an inversion in body weight variation between post-calving and beginning of the breeding season - cows with the lowest average weight gain pre- and post-calving presented the highest weight gains or the lowest weight losses during the breeding season on natural pastures.

The area managed at a stocking rate of $320 \mathrm{~kg} / \mathrm{BW} / \mathrm{ha}$ did not accumulate forage, despite the good rainfall levels of 133, 128 and $145 \mathrm{~mm}$ recorded in October, November, and December, respectively. This demonstrates that the stocking rate used on this soil and in this environment was excessive, precluding the supply of the nutritional requirements of breeding cows, including spring and beginning of summer. In January, the situation deteriorated due to a rainfall of merely $48 \mathrm{~mm}$; forage mass grew due to the $145 \mathrm{~mm}$ of rainfall that occurred by the end of
December. However, a stocking rate of $320 \mathrm{~kg} / \mathrm{ha}$ promoted good reproductive performance in other soils of the same Pampa ecosystem when initial forage availability is higher than 2,500 kg/DM/ha (Quadros \& Lobato, 1996; Pötter \& Lobato, 2004). Lower stocking rates, of $240 \mathrm{~kg} / \mathrm{ha}$, allows achieving $2500 \mathrm{~kg} / \mathrm{DM} / \mathrm{ha}$ during its application (Simeone \& Lobato, 1996), influencing body condition score, weight gain, and reproductive performance. Weather changes and their effects on natural pasture quantity and quality in calving-to-fattening systems requires working with lower stocking rates and higher forage availability. In pasture-based systems, with no supplementation, nutrient availability is rarely excessive; on the contrary, the nutritional levels usually limits the expression of the genetic potential of the animal. (Freetly, 1999).

Experimental results have shown that weight gain and body condition changes during breeding are factors that determine subsequent reproductive responses (Simeone \& Lobato, 1996; Lobato et al., 2000).

In the second half of the breeding season, all systems resulted in slightly higher weight gains $(\mathrm{P}>0.05)$ than those obtained in the systems of post-calving on natural pastures (Table 3). Pötter \& Lobato (2004) worked with a stocking rate of $320 \mathrm{~kg} / \mathrm{ha}$ and determined almost the double of the weight gain obtained in the present study ( $382 \mathrm{~g} /$ day), with a minimum forage mass of 2,500 kg/ha, resulting from higher than normal rainfall in December (90 $\mathrm{mm}$ ) and January (195 mm). Consequently, no weight gain differences were observed among cows submitted to early or conventional weaning (396 vs. 382 g/day, respectively).

There was no difference $(\mathrm{P}>0.05)$ among systems in body weight variation during the entire breeding season, and the weight differences were caused by the treatments applied from pre-calving until the beginning of the breeding season. Similar results were obtained by Lobato et al. (1998a), who also used improved pastures pre- and/or post-calving or only natural pastures. 
Average body weights at the end of the breeding season regarded to those determined at the beginning of the experiment, on $7 / 1 / 2005$, evidence body weight losses of 16.7 and $5.7 \mathrm{~kg}$ in cows in the systems of natural pastures pre-calving, whereas those using improved pastures, 5.9 and $34.4 \mathrm{~kg}$ weight gains were obtained. Lobato et al. (1998b) observed a similar trend, since cows managed exclusively on natural pastures pre-calving lost $28 \mathrm{~kg}$ by the end of the breeding season. In the systems with improved pastures, with 73 days pre-calving and 40 days post-calving, weight loss was $3.6 \mathrm{~kg}$, whereas with 89 days pre-calving and 52 days post-calving, average weight gain was $24.1 \mathrm{~kg}$.

The importance of achieving adequate body weight and body condition score at calving or maintaining or improving these parameters until the beginning of the breeding season, as well as maintaining them during the breeding season, is related to time of conception (Spitzer et al., 1995). The later cows conceive during the breeding season, the later they will calve, thereby reducing the interval calvingend of breeding in the next season (Freetly, 1999; Pötter \& Lobato, 2004), leaving less time for the cow to conceive during breeding seasons of 90 days, at the most.

Cows submitted to the system using improved pastures during both periods, pre- and post-calving, presented the highest pregnancy rate (82.3\%) due to their higher body weights and body condition scores in the beginning and end of the breeding season. These females presented exactly $85 \%$ of the weight of cows in good body condition score in the beginning of the breeding season, and weighted $442.7 \mathrm{~kg}$ by the end of the season, or $85 \%$, which is $3.0 \%$ lower than the body weight recommended by Rovira (1996). The pregnancy rate obtained with system using exclusively improved pasture was different $(\mathrm{P}<0.05)$ only from that obtained with exclusively natural pastures $(52.7 \%)$, where cows maintained 3.4 body condition score in the beginning of mating. Lobato et al. (1998a) observed similar effects in cows maintained on natural pastures with or without supplementation of low-quality hay, with cows on improved pastures preand post-calving presenting $95.2 \%$ pregnancy rate and shorter calving interval (380 days). Cows maintained on improved pastures for 70 days post-calving presented $86.4 \%$ pregnancy rate and a calving interval of 430 days. Cows grazing on natural pastures pre- and post-calving with or without supplementation of low-quality hay, had lower pregnancy rates, of 66.7 and 35\%, respectively.

Lobato et al. (1998b) did not observe significant differences in pregnancy rates among cows maintained on natural pastures pre- and post-calving (81.3\%) and those supplemented up to $65 \%$ of their protein requirements and $34 \%$ of their energy requirements (77.8\%). However, cows managed on improved pastures presented 100 and 93.1\% pregnancy rates $(\mathrm{P}>0.05)$. Working with cows with low body weights and body condition scores and managed for 60 days post-calving on improved pastures, Polli \& Lobato (1985) obtained higher weight gain (634 vs. -10 g/day) as compared to those maintained on natural pastures; however, the obtained pregnancy rates were not economically justifiable(21.7 vs. $0.0 \%$, respectively).

Despite the lack of statistical difference $(\mathrm{P}>0.05)$, the pregnancy rate obtained with the system of natural pastures pre- and post-calving (52.7\%) was numerically lower than that determined with the systems of natural pastures only pre-calving (65.8\%) or only post-calving (62.8\%). In practical terms, this means a difference of 13 calves per 100 lactating cows, with consequences on outcome rates and genetic improvement processes (Pötter et al., 1998; Beretta et al., 2002). This emphasized the need to use moderate stocking rates on natural pastures (Quadros \& Lobato, 1996; Fagundes et al., 2003; Pötter \& Lobato, 2004) and/or improved pastures in order to obtain better reproductive indexes (Lobato et al., 1998a,b, 2000). Pregnancy rates were not different among systems possibly due to the low number of experimental animals per management system. However, under commercial systems, or when the effect of year on the same commercial herd is considered (Vieira et al., 2005b), pregnancy rates are 10 to $13 \%$ higher in cows with calves, which affects outcome rates and selection opportunities in subsequent years.

Heifers submitted to the system of improved pastures post-calving presented 417.2 and $417.3 \mathrm{~kg}$ body weight at the beginning and end of the breeding season, corresponding to $80 \%$ of the required weight, while Rovira (1996) recommends 85 and $88 \%$ of a mature weight of $520 \mathrm{~kg}$ of

Table 4 - Pregnancy rate according to forage system

\begin{tabular}{lcc}
\hline Pasture system & Pregnant & Not pregnant \\
\hline Natural pre- and post-calving & 19 & 17 \\
Natural pre-calving and improved post-calving & 25 & 13 \\
Improved pre-calving and natural post-calving & 22 & $62.7 \mathrm{~b}$ \\
Improved pre- and post-calving & 28 & 13 \\
\hline
\end{tabular}

Means in the same column followed by different letters are different $(\mathrm{P}<0.05)$ by Chi-Square test. 
cows in good body condition. Similarly, cows on natural pastures post-calving had 409.8 and $416.2 \mathrm{~kg}$ body weight at the beginning and end of the breeding season, corresponding to 79 and $80 \%$ mature cow weight, respectively, which were 6 and $8 \%$ below the requirements. During the breeding season, body condition scores of heifers in the natural pasture systems practically did not change, whereas in the system of exclusively improved pastures, heifers lost 0.19 body condition score.

Fagundes et al. (2003) compared stocking rates of 280 and $360 \mathrm{~kg} / \mathrm{ha}$ on natural pastures. The latter corresponds to the requirement of the Instituto Nacional de Colonização e Reforma Agrária (INCRA) as an indicator of productivity in most beef-cattle farms in Rio Grande do Sul. Those authors verified lower $(\mathrm{P}<0.05)$ pregnancy rate at the higher stocking rate $(22.56 \%$ vs. $67.56 \%$, respectively), and concluded that the stocking rate of $360 \mathrm{~kg} / \mathrm{ha}$ is ecologically and economically unfeasible, as it results in low pregnancy rates and long calving intervals.

In a study carried out on natural pastures at lower stocking rates (240 and $320 \mathrm{~kg} / \mathrm{ha}$ ) and improved pastures, Pötter \& Lobato (2004) did not find significant differences $(\mathrm{P}>0.05)$ among pastures and stocking rates due to the high obtained pregnancy rates, of 93.8, 90.6 and 100\%, respectively. These results were attributed to the adequate body condition score of the cows (average of 3.63) in the beginning of the breeding season. However, stocking rates in natural pastures and improved pastures affected stocking rates during the breeding season: 21 days after the beginning of mating, 15.6 and $17.9 \%$ of the cows at $240 \mathrm{~kg} /$ ha stocking rate and those on improved pastures, respectively, were pregnant, whereas none of those at $320 \mathrm{~kg} / \mathrm{ha}$ had conceived. After 42 days of mating, 46.9 and $71.4 \%$ of the cows at the lower stocking rate and on improved pastures were pregnant, respectively, whereas only $37.5 \%$ of the cows at the higher stocking rates had conceived.

Similarly, in the present study, gestation time was estimated using ultrasound examination 37 days after the bulls were removed from the herd. The examination determined gestation times of $41,52,42$, and 61 days for natural pastures pre- and post-calving; natural pastures only pre-calving; natural pastures only post-calving; and improved pastures pre- and post-calving, respectively. Therefore, in average, heifers submitted to the system of improved pastures pre- and post-calving conceived during the first ten days, those in the system of natural pastures pre-calving and improved pastures post-calving during the first 20 days, whereas those maintained in the systems of natural pastures during both periods, or only post-calving conceived during the first 30 days of the breeding season.
The lowest interval between the beginning of the breeding season and conception obtained with the system of improved pastures is a result of the higher average body weights (421.2 and $442.1 \mathrm{~kg}$ ) and body condition scores (3.59 and 3.76) at calving and beginning of mating promoted by the higher nutritional level offered during the 130 days pre- and post-calving on improved pastures (Tables 1 and 3 ). Wright et al. (1987) attribute a 43-day reduction in postcalving anoestrus for each point of increase in body condition score at calving.

The intermediate average interval of 20 days between the beginning of the breeding season and conception obtained with the system of improved pastures pre-calving and improved pastures post-calving relative to the other intervals obtained with the systems of improved pastures or natural pastures pre- and post-calving is attributed to the post-calving weight gain of $503 \mathrm{~g} /$ day on improved pastures, which was slightly higher than that obtained with the system of improved pastures only post-calving, but significantly higher than those obtained by cows maintained or changed to natural pastures post-calving (176 and -219 g/day, respectively). That weight gain allowed increasing body weight and body condition score until the beginning of mating, stimulating the return of the reproductive activity (Table 1 ).

In the system of improved pastures pre-calving and natural pastures post-calving, post-calving weight loss until 11/7/2005 (-219g/day) and, then during the first half of the breeding season (-102 $\mathrm{g} /$ day) resulted in higher inhibition of estrus activity, and consequent similar gestation time as that of heifers managed on natural pastures pre- and postcalving. This was caused by the low dry matter availability, which was lower than $1000 \mathrm{~kg} / \mathrm{ha}$, considered insufficient to produce pregnancy rates higher than 85\% (Simeone \& Lobato, 1996; Fagundes et al, 2003; Pötter \& Lobato, 2004). Lobato \& Barcelos (1992) verified that cows maintained on improved pastures oats/ryegrass) for 60 days post-calving presented higher pregnancy rates (77.9\%) as compared to those grazing only on natural pastures (27.7\%). Calving interval (436 days) and mating-conception interval (48 days) were significantly lower in animals maintained exclusively on improved pastures relative to those maintained exclusively on natural pastures (calving interval of 588 days and mating-conception interval of 63 days).

When working with different forage systems pre- and post-calving, body weight and body condition score evolution must be closely monitored, as well as their targets at calving and subsequent times, which are associated to natural pasture quality, and particularly, dry matter availability. 


\section{Conclusions}

Primiparous heifers managed on improved pastures pre- and post-calving present higher body weight and body condition score in the beginning of the breeding season, higher pregnancy rate, and conceive earlier. The management of heifers on improved pastures pre- or postcalving does not influence body weight at the beginning of the breeding season or pregnancy obtained with these systems. However, cows grazing on improved pastures post-calving conceive earlier. Primiparous cows managed on natural pastures pre- and post-calving at a stocking rate of $320 \mathrm{~kg} / \mathrm{ha}$ and low forage availability present the lowest pregnancy rates and conceive later.

\section{References}

ALLDEN, W.G. Energy and protein supplementation for grazing livestock. In: MORLEY, F.H.V. (Ed.) Grazing animals. Amsterdam: Elsevier, 1981. p.259-308.

ASSOCIATION OF OFFICIAL ANALITICAL CHEMISTS AOAC. Official methods of analysis. 14.ed. Washington, D.C.: 1984. 1141p.

BERETTA, V.; LOBATO, J.F.P.; MIELITZ NETTO, C.G.A. Produtividade e eficiência biológica de sistemas pecuários de cria diferindo na idade das novilhas ao primeiro parto e na taxa de natalidade do rebanho do Rio Grande do Sul. Revista Brasileira de Zootecnia, v.30, n.4, p.1278-1286, 2001.

BERETTA, V.; LOBATO, J.F.P.; MIELITZ NETTO, C.G.A. Produtividade e eficiência biológica de sistemas de produção de gado de corte de ciclo completo no Rio Grande do Sul. Revista Brasileira de Zootecnia, v.31, n.2, p.991-1001, 2002 (supl.).

BERETTA, V.; LOBATO, J.F.P. Sistema "um ano" de produção de carne: avaliação de estratégias alternativas de alimentação hibernal de novilhas de reposição. Revista Brasileira de Zootecnia, v.27, n.1, p.157-163, 1998.

CACHAPUZ, J.M.; LOBATO, J.F.P.; LEBOUTE, E.M. Pastagens melhoradas e suplementos alimentares no comportamento reprodutivo de novilhas com primeira cria. Pesquisa Agropecuária Brasileira, v.25, n.3, p.445-454, 1990.

FAGUNDES, J.I.B.; LOBATO, J.F.P.; SCHENKEL, F.S. Efeito de duas cargas animais em campo nativo e de duas idades de desmama no desempenho de vacas de corte primíparas. Revista Brasileira de Zootecnia, v.32, n.6, p.1722-1731, 2003.

FERRELL, C.L. Effects of post weaning rate of gain on onset of puberty and productive performance of heifers of different breeds. Journal of Animal Science, v.55, n.6, p.1272-1283, 1982

FREETLY, H.C. The replacement heifer and the primiparous cow. In: REUNIÃO ANUAL DA SOCIEDADE BRASILEIRA DE ZOOTECNIA, 36., 1999, Porto Alegre. Anais... Porto Alegre: Sociedade Brasileira de Zootecnia, 1999. p.241-249.

GOTTSCHALL, C.S.; LOBATO, J.F.P. Comportamento reprodutivo de vacas de corte, primíparas, submetidas a três lotações em campo nativo. Revista Brasileira de Zootecnia, v.5, n.1, p.47-57, 1996.

HAYDOCK, K.P.; SHAW, N.H. The comparative yield method for estimating dry matter yield of pasture. Australian Journal of Experimental Agriculture and Animal Husbandry, v.15, n.72, p.663-670, 1975.
HERD, D.H.; SPROTT, L.R. Body condition, nutrition and reproduction of beef cows. [S.I.]: The Texas A\&M University System, 1996. Texas Agricultural Extension Service, 1996. 11p.

HIGHT, G.K. The effects of the under nutrition in late pregnancy on beef cattle production. New Zealand Journal of Agricultural Research, v.9, n.3, p.479-490, 1966.

HODGSON, J. Influence of sward characteristics on diet selection and herbage intake by the grazing animal. In: NUTRITIONAL LIMITS TO ANIMAL PRODUCTION FROM PASTURES, 1981, St. Lucia, Queensland. Proceedings... Queensland: CSIRO, 1981. p.153-166.

LOBATO, J.F.P.; BARCELLOS, J.O.J. Efeitos da utilização de pastagem melhorada no pós-parto e do desmame aos 100 ou 180 dias de idade no desempenho reprodutivo de vacas de corte. Revista da Sociedade Brasileira de Zootecnia, v.21, n.3, p.385-395, 1992.

LOBATO, J.F.P.; ZANOTTA JR., R.L.D.; PEREIRA NETO, O.A. Efeitos das dietas pré e pós-parto na eficiência reprodutiva de vacas primíparas de corte. Revista Brasileira de Zootecnia, v.27, n.5, p.857-862, 1998a.

LOBATO, J.F.P.; DERESZ, F.; LEBOUTE, E.M. et al. Pastagens melhoradas e suplementação alimentar no comportamento reprodutivo de vacas de corte primíparas. Revista Brasileira de Zootecnia, v.27, n.1, p.47-53, 1998b.

LOBATO, J.F.P.; MÜLLER, A.; PEREIRA NETO, O.A. et al. Efeitos da idade à desmama dos bezerros sobre o desempenho reprodutivo de vacas de corte primíparas. Revista Brasileira de Zootecnia, v.29, n.6, p.2013-2018, 2000.

LOBATO, J.F.P. A "vaca ideal" e seu manejo em sistemas de produção de ciclo curto. In: SIMPÓSIO DA CARNE BOVINA: DA PRODUÇÃO AO MERCADO CONSUMIDOR, 1., 2003, São Borja. Anais... Porto Alegre: Ed. UFRGS, 2003. p.9-47.

LOWMAN, B.G. Feeding in relation to suckler cow management and fertility. Veterinary Records, v.117, p.80-85, 1985.

LOWMAN, B.G.; SCOTT, N.; SOMERVILLE, S. Condition scoring beef cattle. Edinburgh: East of Scotland College of Agriculture, 1976. 8p. (Bulletin, 6).

MORRISON, D.G.; SPITZER, J.C.; PERKINS, J.L. Influence of pre-partum body condition score change on reproduction in multiparous beef cows calving in moderate body condition. Journal of Animal Science, v.77, n.5, p.1048-1054, 1999.

NATIONAL RESEARCH COUNCIL - NRC. Nutrient requirement of beef cattle. 7. rev. ed. Washington, D.C.: National Academy Press, 1996. 242p.

PILAU, A.; LOBATO, J.F.P. Suplementação energética préacasalamento aos 13/15 meses de idade para novilhas de corte: desenvolvimento e desempenho reprodutivo. Revista Brasileira de Zootecnia, v.38, n.12, p.2482-2489, 2009.

POLLI, V.A.; LOBATO, J.F.P. Utilização de pastagens temperadas por diferentes categorias do rebanho: I. Vacas com cria. In: REUNIÃO ANUAL DA SOCIEDADE BRASILEIRA DE ZOOTECNIA, 1985. Camboriú. Anais... Camboriú: SBZ, 1985. v.22, p.503.

PÖTTER, L.; LOBATO, J.F.P.; MIELITZ NETTO, C.G.A. Produtividade de um modelo de produção para novilhas de corte primíparas aos dois, três e quatro anos de idade. Revista Brasileira de Zootecnia, v.27, n.3, p.613-619, 1998.

PÖTTER, L.; LOBATO, J.F.P.; MIELITZ NETTO, C.G.A. Análises econômicas de modelos de produção com novilhas de corte primíparas aos dois, três e quatro anos de idade. Revista Brasileira de Zootecnia, v.29, n.3, p.861-870, 2000.

PÖTTER, B.A.A.; LOBATO, J.F.P. Efeitos de carga animal, pastagem melhorada e da idade de desmame no comportamento reprodutivo de vacas primíparas. Revista Brasileira de Zootecnia, v.33, n.1, p.192-202, 2004.

QUADROS, S.A.F.; LOBATO, J.F.P. Efeitos de lotação no comportamento reprodutivo de vacas de corte primíparas. Revista da Sociedade Brasileira de Zootecnia, v.25, n.1, p.22-35, 1996. 
RICHARDS, M.W.; SPITZER, J.C.; WAGNER, M.B. Effect of varying lives of post partum nutrition and body condition at calving on subsequent reproductive performance in beef cattle. Journal of Animal Science, v.62, n.2, p.300-306, 1986.

ROCHA, M.G.; PILAU, A.; SANTOS, D.T. et al. Desenvolvimento de bezerras de corte submetidas a diferentes sistemas alimentares. Revista Brasileira de Zootecnia, v.33, n.6, p.2123-2131, 2004 (supl.2).

ROSADO JR, A.G.; LOBATO, J.F.P. Application of a model of management by macroprocesses to a beef cattle enterprise: a case study. Revista Brasileira de Zootecnia, v.38, n.11, p.2280-2288, 2009.

ROVIRA, J. Manejo nutritivo de los rodeos de cría en pastoreo. 1.ed. Montevideo: Hemisferio Sur, 1996. p.288.

SIMEONE, A.; LOBATO, J.F.P. Efeitos da lotação animal em campo nativo e controle da amamentação no comportamento reprodutivo de vacas de corte primíparas. Revista Brasileira de Zootecnia, v.25, n.6, p.1216-1227, 1996.

SPITZER, J.C.; MORRISON, D.G.; WETTEMANN, R.P. et al. Reproductive responses and calf birth and weaning weights as suggested by body condition at parturition and postpartum weight gain in primiparous beef cows. Journal of Animal Science, v.73, n.5, p.1251-1257, 1995.

STATISTICAL ANALYSES SYSTEM - SAS. User's guide statistics. 4.ed., Version 6, Cary: 1997. v.2, 943p.

STEEL, R.G.D.; TORRIE, J.H. Bioestadística: Principios y procedimientos. Cidade do México: McGraw Hill, 1989. 622p.
STRECK, E.V.; KÄMPF, N.; DALMOLIN, R.S.D. et al. Principais classes de solos identificadas no Rio Grande do Sul. In: STRECK, E.V.; KÄMPF, N.; DALMOLIN, R.S.D. et al. (Eds). Solos do Rio Grande do Sul. Porto Alegre: EMATER/RS; UFRGS. 2002. 107p.

VIEIRA, A.; LOBATO, J.F.P.; CORREA, E.S. et al. Produtividade e eficiência de vacas Nelore em pastagem de Brachiaria decumbens Stapf nos Cerrados do Brasil Central. Revista Brasileira de Zootecnia, v.34, n.4, p.1357-1365, $2005 a$.

VIEIRA, A.; LOBATO, J.F.P.; TORRES JR., R.A.A. et al. Fatores determinantes do desempenho reprodutivo de vacas Nelore na região dos Cerrados do Brasil Central. Revista Brasileira de Zootecnia, v.34, n.6, p.2408-2416, 2005b (supl.).

VIEIRA, A.; LOBATO, J.F.P.; CORRÊA, E.S. et al. Desenvolvimento e desempenho reprodutivo de novilhas Nelore criadas a pasto nos Cerrados-Oeste brasileiro. Revista Brasileira de Zootecnia, v.35, n.1, p.186-192, 2006.

WILTBANK, J.N.; ROWDEN, W.W.; INGALLS, J.E. et al. Effect of energy level on reproductive phenomena of mature Hereford cows. Journal of Animal Science, v.21, n.3, p.219-225, 1962 .

WRIGHT, I.A.; RHIND, S.M.; RUSSEL, A.J.F. et al. Effects of body condition, food intake and temporary calf separation on duration of the post-partum anoestrus period and associated LH, FSH and prolactin concentrations in beef cows. Animal Production, v.45, n.2, p.1049-1056, 1987. 